"Development of industrial parks and a new livelihood strategy for the people in Vietnam"

\begin{tabular}{|c|c|}
\hline AUTHORS & $\begin{array}{l}\text { Thanh Thuy Cu } \\
\text { Tuan Anh Nguyen }\end{array}$ \\
\hline ARTICLE INFO & $\begin{array}{l}\text { Thanh Thuy Cu and Tuan Anh Nguyen (2021). Development of industrial parks } \\
\text { and a new livelihood strategy for the people in Vietnam. Problems and } \\
\text { Perspectives in Management, 19(1), 221-230. doi:10.21511/ppm.19(1).2021.19 }\end{array}$ \\
\hline DOI & http://dx.doi.org/10.21511/ppm.19(1).2021.19 \\
\hline RELEASED ON & Tuesday, 02 March 2021 \\
\hline RECEIVED ON & Saturday, 26 December 2020 \\
\hline \multirow[t]{2}{*}{ ACCEPTED ON } & Thursday, 25 February 2021 \\
\hline & $(c c)$ EY \\
\hline LICENSE & $\begin{array}{l}\text { This work is licensed under a Creative Commons Attribution } 4.0 \text { International } \\
\text { License }\end{array}$ \\
\hline JOURNAL & "Problems and Perspectives in Management" \\
\hline ISSN PRINT & $1727-7051$ \\
\hline ISSN ONLINE & $1810-5467$ \\
\hline PUBLISHER & LLC "Consulting Publishing Company "Business Perspectives" \\
\hline FOUNDER & LLC "Consulting Publishing Company "Business Perspectives" \\
\hline & 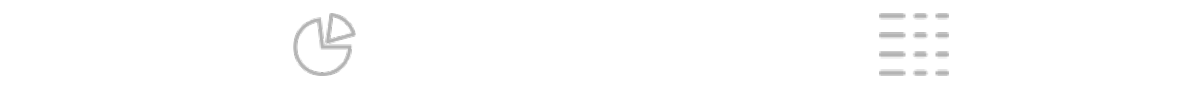 \\
\hline NUMBER OF REFERENCES & NUMBER OF FIGURES \\
\hline 32 & 4 \\
\hline
\end{tabular}

(C) The author(s) 2021. This publication is an open access article. 


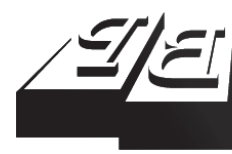

\section{BUSINESS PERSPECTIVES}

()

LLC "CPC "Business Perspectives"

Hryhorii Skovoroda lane, 10

Sumy, 40022, Ukraine

www.businessperspectives.org

Received on: $26^{\text {th }}$ of December, 2020

Accepted on: $25^{\text {th }}$ February, 2021

Published on: $2^{\text {nd }}$ of March, 2021

() Thanh Thuy $\mathrm{Cu}$, Tuan Anh Nguyen, 2021

Thanh Thuy Cu, Dr., Lecturer, Faculty of Urban Management, Hanoi Architectural University, Vietnam. (Corresponding author)

Tuan Anh Nguyen, Dr., Vice Rector, Hanoi Architectural University, Vietnam.

\title{
DEVELOPMENT OF INDUSTRIAL PARKS AND A NEW LIVELIHOOD STRATEGY FOR THE PEOPLE IN VIETNAM
}

\begin{abstract}
This study is designed to analyze the influence of industrial park (IP) development on the lives of people living around the IPs in Vietnam and on new livelihood strategies for people after the industrial park was built and developed. Data were collected from a survey of 409 people living around industrial parks in three regions of Vietnam (Northern, Central, and South Vietnam). The findings show that the livelihood resources, such as financial resources, physical resources, social resources, and natural resources, have a positive relationship with people's livelihoods after industrial park construction and development; though, the degree of influence of these resources is different. Whereas human resources have a positive effect (through the item - additional jobs created by the industrial park) and a negative effect on income (through the object - the unemployed labor by the industrial park built and developed). The findings also show that most households surveyed responded that their lives had changed for the better (about $41.36 \%$ compared to nearly $28.91 \%$ of households surveyed who said their income had decreased).
\end{abstract}

Keywords

JEL Classification

\section{INTRODUCTION}

The development of industrial parks has become an inevitable trend in countries, including developing ones such as Vietnam. The development of industrial parks has contributed to creating a technical infrastructure, thereby contributing to attracting investment capital from domestic and international investors. From there, contribute to the economic development of countries, as well as solve problems of employment and social difficulties for host countries.

The development of industrial parks brings benefits to the country by creating more jobs for local people, promoting economic development of localities where the IPs are located, etc. Since then, it contributes to stabilizing people's lives and socio-economic development.

However, besides those benefits, the development of IPs will also cause some difficulties, which are as follows: Firstly, when IPs are built, it is necessary to acquire a part of the agricultural land and residential land of the people. At that time, people will receive compensation money from the acquisition of that land. But if the compensation is not used reasonably, it will lead to unemployment due to the loss of capital goods in the future, people's life will become more difficult. Secondly, the IPs built will attract a great workforce from diverse places to work in projects and enterprises. 
From that, there will arise social problems in the locality where the IP is built if not managed well. New requirements for health, education, and infrastructure will also be higher at the local level.

In Vietnam, by the end of October 2020, there are 369 IPs established, the total natural land area is about 113.3 thousand ha, industrial land for lease is about 73.6 thousand ha. Among them, 280 IPs are in operation with industrial land for a lease of about 56.6 thousand hectares. Investors rented about 39.8 thousand hectares of industrial land (occupancy rate of industrial land is about 70.1\%). IPs in operation have attracted about 9,845 domestic projects with a total investment of about VND 2.34 million, while projects with foreign investment capital - about 10,055 projects with a registered capital of about USD 198 billion.

However, besides these achievements, the construction of IPs also caused disadvantages to the lives of people whose land is acquired as follows: According to the statistics of the Ministry of Labor, War Invalids and Social Affairs, on average 1 hectare of agricultural land creates jobs for 13 to 15 workers, and each household whose land is acquired to build an IP will have 1.5 unemployed. Thus, taking the land to develop IPs in Vietnam causes high unemployment in the countryside. Since then, the social problems that arise are relatively large.

The effects of IP development on people's lives in Vietnam are relatively large, with residents affected (both positive and negative) from IPs; Residents living around industrial parks will need new livelihood strategies to cope with the changes caused by the IPs development. Livelihood strategies related to new jobs, changing new resources to generate income for their own families, etc. For the positive effects of IP development on the people, new livelihood strategies are needed to bring into these positive impacts, and these new livelihood strategies could be new jobs, using new means of labor to generate additional income for people. For the negative influences, people need to have plans to adapt to the new conditions to ensure their own and their families' lives.

\section{LITERATURE REVIEW}

Studies of the influence of IP construction on socio-economic development of countries mentioned by the authors, the data used in these studies have a relatively large homogeneity, the data used through the direct survey of subjects directly affected by the development of IPs. Typical for these studies are those by Milan et al. (2013); the authors used data collected through surveying enterprises operating in IPs of the Czech Republic. The objective of the study is to evaluate the effectiveness of IPs as an effective tool to support the socio-economic situation of the Czech Republic. Meanwhile, Susur et al. (2019) have affirmed the great position of the sustainable development of IPs, data for the study was collected from 104 EcoIndustrial Parks (EIPs) from 24 different countries. The findings reveal the development of EIPs in diverse geographic areas will vary. From the research results, the authors have proposed solutions to develop EIPs in a more sustainable direction. Liang et al. (2015) also focused on researching the development of EIPs in China.
The studies by Hyeong et al. (2016), Blomstrom and Kokko (2002), and Ramona (2008) have similar findings, namely they show that IPs development has socio-economic effects, however, in the long term; the development of IPs is carried out towards green and sustainable industry.

Liang et al. (2017) and Nguyen et al. (2017) focused more specifically on the benefits that industrial parks bring to countries. Research by Liang et al. (2017) proposed location and policy implications for China; Nguyen et al. (2017) conducted a study in Vietnam and provided the policy implications for the development of IPs through the attraction of resources in the context of economic integration in Vietnam.

On the micro level, some studies by Dai et al. (2013), Bui et al. (2013), and Bury (2004) focused more on exploiting the impact of IPs development on the lives of people living around the IPs. These studies focus on those who lose agricultural land to build IPs, the impact of this target group, so there are appropriate recommendations suggesting new de- 
signs of fertility strategies for them. However, according to the research team's point of view, the construction of IPs affects not only the groups of people whose land is acquired, but also the people living around the IPs. Besides, the effects include both direct and indirect effects, positive and negative effects. Therefore, having inherited the above research, the research team should develop and implement this research on a wider scale.

Moreover, some authors focused on the factors affecting the livelihoods of households due to the effects of industrialization and urbanization (Le, 2007; Benayas et al., 2007; Bryceson, 1996; Jansen et al., 2006, etc.). The data was collected from the survey of household lives affected by industrialization and urbanization of the selected site. These studies have compared the income of households between two times before and after being affected by this process. Some factors identified by the research team that affect the livelihoods of households include education level, number of employees per household, gender, the land area acquired due to industrialization, urbanization, socialization, participation in social organizations, etc. Also focusing on research on the effects of industrialization on people's livelihoods, Nguyen et al. (2018), Ramcharran (2017), and Nguyen and Nguyen (2020) concentrate more on defining livelihood strategies for households whose land is acquired. Additionally, these studies assess the important role of households' education level and land acreage in people's new livelihood strategies when affected by industrialization. Based on those research findings, recommendations are given to build people new plans to stabilize their lives. Specifically, Saumik and Sarma (2013) analyzed the positive and negative effects of IP development on people's livelihoods; there is a negative impact, the author pointed out, because withe the development of the industrial zone, the transportation system is better, but the local people's income decreases. The reason is that people in that area, in the past, had a livelihood strategy of agriculture and fisheries; when the IP was built, they lost their labor materials, leading to a decrease in income. Tran (2013) and Nguyen and Bui (2011) analyzed factors affecting people's income, including education level, labor size, support policies, etc. However, Tran (2013) research subjects are households whose land is acquired in urban areas in
Vietnam, while the research subjects of Nguyen and Bui (2011) are households of the Mekong Delta region. Both of these studies used data from direct surveys of people in the study area.

The above studies focus on analyzing the effects of industrialization and urbanization on people's livelihoods in different approaches. However, the common points of the above studies aim to examine the direct influences of urbanization and industrialization, develop IPs for households whose land is acquired, and grow a new livelihood strategy for these subjects. The research framework used is quite unanimous when using the DFID research framework (1999). However, in the view of the authors, the development of IPs affects two groups of people whose land is acquired, as well as people who do not have land acquired but live around IPs. IP development brings numerous benefits besides the negative impacts on people's lives.

Residents living around industrial parks will need new livelihood strategies to cope with the changes caused by the IPs development. Livelihood strategies related to new jobs, changing new resources to generate income for their own families, etc. For the positive effects of IP development on the people, new livelihood strategies are needed to bring into these positive impacts, and these new livelihood strategies could be new jobs, using new means of labor to generate additional income for people. For the negative influences, people need to have plans to adapt to the new conditions to ensure their own and their families' lives.

\section{RESEARCH METHODOLOGY}

\subsection{Data collection methods}

To have data for analysis and research, a survey sample of households living around and affected by IPs was developed. The authors' survey questionnaire was based on the survey sample of Household living standards of the General Statistics Office (GSO, 2006). In this survey form, the team was divided into three parts: Part 1 is the information of the survey object, Part 2 is the content on impacts of IP development on people's livelihoods (divided by livelihood resource groups), and Part 3 is the new livelihood strategies of the people. 
For the survey, three provinces were surveyed, representing three regions of Vietnam, namely:

- The Bac Ninh province is a representative province in the North of Vietnam;

- Da Nang City is a locality that represents the central region of Vietnam; and

- The Binh Duong province is the locality representing the southern region of Vietnam.

All three of these provinces are among the leading IPs in Vietnam. Therefore, when studying the effects of IP development on people's livelihoods, it will also correctly reflect a general impact of IP development on people in Vietnam.

About the survey scale: According to Nguyen (2014), the minimum number of observations for statistical calculations is 100 . The author discovers questionnaires in three regions of Vietnam; each region will issue 200 survey forms; the total number of questionnaires is 600 . After issuing the questionnaires, a direct survey of the surveyed subjects was conducted; the results collected 483 survey forms.

With 483 surveys collected, the authors entered data and discarded unsatisfactory surveys, 409 questionnaires were satisfying the survey information requirement retained to perform statistical calculations. Time of survey: From January 2020 to June 2020.

\subsection{Data analysis method}

To analyze the level of influence of IP development on people's livelihoods, the OLS regression model is used; below are the variables.

\subsubsection{Dependent variable}

Livelihoods of households living around IPs, the scale (item) chosen to represent this livelihood variable is the household income (Y): Household income is understood as the amount of income that the household earns each year, unit of calculation: Million VND/year. This variable was selected based on the views of Siegel (2005), Nguyen and Bui (2011), Le et al. (2020), Tran (2013), and Tran and $\mathrm{Vu}(2014)$.

\subsubsection{Independent variables}

The independent variables were selected based on an overview of previous studies and based on the framework of the analysis of sustainable livelihoods of DFID (1999) with groups of livelihood resources, namely:

- For human resources of households, the scales selected include: Age of the household head (Age), the number of additional jobs after the IP is built and developed (Emp); and the number of unemployed workers due to construction and development of IPs (Unemp). Each of these scales (items) has the direction and degree of influence on household income; in particular, the following is expected:

Age of the household head (Age) is positively related to the household income; however, these heads of households are in the working-age group, the author's point of view supports the views of Nguyen and Bui's (2011), Huynh and Mai (2011), Tran (2013), Tran and Vu (2014), and Siegel (2005).

The number of additional jobs after the IP is built and developed (Emp): The total number of employees who have additional jobs when the IP is built and developed, including direct workers who work directly at factories and indirectly work by developing IPs. The relationship of this scale to household income is expected to be in the same direction (Le, 2007; Tran, 2013; and Le et al., 2020).

Number of unemployed workers due to the construction and development of IPs (Unemp): The entire labor force in each household was unemployed caused by land acquisition. The relationship of this variable with the dependent variable is an inverse relationship (Nguyen, 2009; Le, 2007; Le et al., 2020).

- For financial resources, the scales selected include: Cost of living of households (Cost); household investment (Invest); compensation amount due to the land acquisition of families (Add); and these scales are expected to have different effects on the income of households.

According to Nguyen and Bui (2011), Tran (2013), Tran and Vu (2014), Siegel (2005), and Huynh 
and Mai (2011), the whole household's cost of living (cost) will increase as the household's income increases. Therefore, the relationship between these two variables is predicted to be in the same direction.

According to Nguyen and Bui (2011), Tran (2013), Tran and Vu (2014), Siegel (2005), Huynh and Mai (2011), etc., when the investment of the households (Invest) increases, income tends to grow in the future.

According to Nguyen (2009) and Nguyen et al. (2006), the amount of compensation for land acquisition of the households (add) will increase with the household income. But, if the funds are not properly used and reinvested, the household income tends to decrease in the future when not adapting to change due to the revocation of capital goods. This will also cause two-sided effects on people's lives, both positive impacts and negative impacts. If that amount is reasonably used, this will have a positive impact on the lives of people when there are new livelihood strategies.

- Social resources: Participation in social organizations, access to social organizations, and supportive policies of the government, as well as local ones, will contribute to supporting people's lives. Inheriting research by Tran and Vu (2014), Nguyen and Bui (2011), Tran (2013), Siegel (2005), Huynh and Mai (2011), etc., this study used the following scales: Access to government support in loans (CS) and participation in social organizations (XH). These variables will contribute indirectly and have a positive effect on people's lives, particularly people's income.

- Physical resources: According to Le et al. (2020), Nguyen and Bui (2011), Tran (2013), and Tran and $\mathrm{Vu}$ (2014), physical resources are taken into account when affecting people's livelihoods, including the transportation system (Infr), electrical system (Elec), and water system (Wat). These factors will have a positive impact on people's income if provided well, will support daily activities, as well as production and business of households. However, according to Saumik and Sarma (2013), when the transport system is better, the household income will decrease, because it directly affects the livelihood strategy of the households living in river areas, where the survey was carried out.

- Natural resources: According to Nguyen (2009), Tran (2013), Tran and Vu (2014), Nguyen and Bui (2011), Siegel (2005), and Huynh and Mai (2011), the location of the household's residential land (VTDD) also has a positive effect on household income, because when being in a favorable position, it will open up new livelihood strategies, create more sources of income for households. In particular, when IPs are built and developed, workers come to work in those IPs, and the demand for supporting services increased a lot. These indirect workers and the provision of additional services will help increase family income.

\section{RESULTS}

It is necessary to examine and check the suitability of the model with existing data, as the results show that the Adjusted R Square coefficient = 0.837, coefficient $\operatorname{Sig}=0.000$, and $F=175.946$; the test shows that a study using a regression model is appropriate.

Table 1. Regression results

\begin{tabular}{l|c|c|c}
\hline \multicolumn{1}{c}{ Items } & $\begin{array}{c}\text { Standardized } \\
\text { coefficients }\end{array}$ & $\mathbf{t}$ & Sig. \\
\hline (Constant) & .151 & -7.001 & .000 \\
\hline Age & .430 & 7.353 & .000 \\
\hline Invest & .191 & 18.191 & .000 \\
\hline Cost & .263 & 6.714 & .000 \\
\hline Add & .129 & 11.865 & .000 \\
\hdashline Infr & .167 & 6.121 & .000 \\
\hdashline Emp & -.135 & 7.222 & .000 \\
\hdashline Unemp & .175 & -5.105 & .000 \\
\hline XH & .048 & 8.322 & .000 \\
\hline CS & .071 & 2.171 & .031 \\
Wat & .053 & 3.299 & .001 \\
\hdashline Elec & .038 & 2.590 & .010 \\
\hline VTDD & & 1.779 & .076 \\
\hline
\end{tabular}

Note: Dependent variable: Y.

The research findings show that for human resources of households, the variables were positively related to income. Specifically, the Age of the 
household head (Age) variable had a standardized coefficient of 0.151 ; the variable Number of additional jobs created when building and developing IPs (Emp) had the standardized coefficient of 0.167 (This variable is positively related to household incomes because when jobs are created, family members will have additional income, which increases the family income). Research findings support the views of Tran (2013), Nguyen and Bui (2011), Tran and Vu (2014), Siegel (2005), Huynh and Mai (2011), and Le et al. (2020).

Meanwhile, the number of unemployed workers has an inverse relationship with the household income, the standardized coefficient is -0.135 . When households have their productive land and their labor materials lost, a part of the people cannot adapt to the new conditions, leading to unemployment. The reason is that when labor recruited to enterprises, production and business establishments in IPs requires professional qualifications, with certain skills, those who cannot meet will find themselves unemployed, which directly affects their lives. Research results support Tran (2013), Le et al. (2020), and Tran and Vu (2014).

Table 2. Survey results on employment when building and developing industrial parks

\begin{tabular}{|c|c|c|c|}
\hline No. & Criteria & Quantity & Density \\
\hline $\mathrm{S}$ & Unit & People & $\%$ \\
\hline \multirow{3}{*}{1} & New labor was created & 323 & 78.97 \\
\hline & self-employment & 136 & 33.25 \\
\hline & $\begin{array}{l}\text { Working in enterprises, } \\
\text { factories of industrial parks }\end{array}$ & 187 & 45.72 \\
\hline 2 & Unemployment & 86 & 21.03 \\
\hline \multicolumn{2}{|r|}{ Total } & 409 & 100 \\
\hline
\end{tabular}

Thus, it can be seen that a huge part of people has new jobs after the IP is built and developed, accounting for about $78.97 \%$ of the total number of survey observations in the studied area. The number of new jobs created mainly from self-employment accounts for about $33.25 \%$. Selfemployment is the job of people around the IP, it provides specific ancillary services such as housing construction and accommodation management for workers working in the IP to rent, provides services such as dining, motels, entertainment, etc. Another part with enough professional qualifications and skills is recruited to work in enterprises, production, and business establish- ments of IPs. A part of people cannot adapt to new conditions, leading to unemployment, which greatly affects families' lives.

Concerning financial resources, the selected scales have the same relationship with the household's income, but the degree of influence is different. Specifically, the standardized coefficient of investment is 0.43 , while the standardized coefficient of the additional variable is 0.263 , which are two variables representing the new livelihood strategy of the people being applied. Every year, people reinvest to generate more income. Despite fluctuations in living conditions, the change and adaptation have made the household's income guaranteed. This research result has supported the views of Tran and Vu (2014), Nguyen and Bui (2011), Tran (2013), Siegel (2005), and Huynh and Mai (2011).

Table 3. Plan for the use of average household compensation

\begin{tabular}{|c|c|c|}
\hline No. & Criteria & Quantity \\
\hline 1 & House construction and repair & 21.76 \\
\hline 2 & $\begin{array}{l}\text { Shop for new living equipment such as } \\
\text { televisions, refrigerators }\end{array}$ & 11.03 \\
\hline 3 & Saving & 7.12 \\
\hline 4 & Investment in production and business & 36.82 \\
\hline 5 & Keep cash for use gradually & 23.27 \\
\hline 6 & Other & 0.76 \\
\hline \multicolumn{2}{|r|}{ Total } & 100 \\
\hline
\end{tabular}

Note: Unit: \%.

The results of the survey showed that using compensation money by households is calculated on average and as a percentage (\%) of the amount of compensation received (this calculation only applies to families whose capital goods are revoked); households use the money according to various purposes.

Households that use their compensation money to invest in new production and business account for $36.82 \%$ of total income from compensation. This investment, if profitable, will lead to a better life, and vice versa. The second-largest amount of money that people use is savings in credit institutions; they think that depositing money in credit institutions will be safe, and they will have savings to spend due to deposit interest each year. A large portion of these funds are used for daily expenses and to build and repair homes. 
In conclusion, when used appropriately, the finance will help change people's lives in a more positive direction.

Social resources: The findings show that participation in social organizations, outreach to social organizations, and supportive policies of the government, as well as local ones, will contribute to supporting people's lives more actively; the results of coefficients of the variables CS and $\mathrm{XH}$ are in the same direction with household incomes. Research results fully support the views of Nguyen and Bui (2011), Tran (2013), Tran and Vu (2014), Siegel (2005), and Huynh and Mai (2011).

As for the natural and physical resources, the variables have a positive relationship with the household's income, namely the coefficient of VTDD variable is 0.038 ; Infr variable coefficient is 0.129 . The research results support the opinions of Nguyen (2009), Tran (2013), Tran and Vu (2014), Nguyen and Bui (2011), Siegel (2005), and Huynh and Mai (2011).

Table 4. Statistics of household income changes after building and developing an IP

\begin{tabular}{c:l|c}
\hline No. & \multicolumn{1}{|c}{ Criteria } & Quantity \\
\hline 1 & Income unchanged when building an IP & 29.73 \\
\hdashline 2 & $\begin{array}{l}\text { Income decreased compared to income } \\
\text { before an IP }\end{array}$ & 28.91 \\
\hdashline & $\begin{array}{l}\text { Income increases compared to when } \\
\text { there is an IP }\end{array}$ & 41.36 \\
\hline & Total & 100 \\
\hline
\end{tabular}

Note: Unit: \%.

The creation and development of an IP has a positive effect on household income thanks to new livelihood strategies. About $41.36 \%$ of the total surveyed households answered that their profits increased compared to the pre-industrial park period. However, nearly $28.91 \%$ of households said that their earnings decreased, and the decrease was caused by using compensation for the wrong purpose, or their family was unemployed. Roughly $29.73 \%$ of surveyed households stated that their family income had not changed.

The research results are the basis for proposing recommendations that help improve the lives of families who are able to adapt to changes in external conditions.

\section{DISCUSSION}

The goal of IP development is to promote the socio-economic development of nations, localities, the fact that the development of IPs in Vietnam has achieved probable results. One of the particular expressions is the livelihood change, which changes the lives of people living around the area where IPs are built and developed.

In addition to the positive impacts that industrial parks have brought to people's lives after construction and development, there are also adverse effects. Minimizing the dark side and promoting the bright side, creating new livelihood strategies are essential and thereby further improving people's lives.

There should be policies to support people in their livelihood transformation such as policies on job creation, social security policies, etc. In particular, the issue of creating jobs for workers after losing productive land is extremely important. With the workers still old enough to be recruited to work in enterprises, there should be preferential policies in career transition training and recruitment priority; they can get into the business. With out-of-date employees, it is necessary to have an orientation to help them choose production and business plans, use the compensation money reasonably and effectively. All these policies must be implemented prior to land acquisition so that workers can change careers immediately after land acquisition and households can sustainably change their livelihoods.

There is a policy for people to contribute capital with land use rights. With this solution, when households have their land acquired, they immediately get compensation money to contribute capital to invest in factories built on their land. So, they become shareholders of the business and enjoy benefits such as ease of admission to work at the enterprise with a stable salary and other preferential regimes such as body insurance, health insurance; receiving profit from investing capital in a business. Besides, enterprises also benefit in the clearance, shorten construction time, quickly put enterprises into operation, avoid project stalling due to failure to reach agreement on clearance with people who lose land; additional capital mobilization channel for enterprises. 
Households that need to use compensation money appropriately should invest in business or invest in career change training, actively research the market, or learn from other households' experiences to change livelihood strategies from agricultural production to handicraft production and services.

The fact is that they feel that IP construction has had a positive impact on their lives; in particular, it is easier for them to get jobs, and their income is higher after they have IPs. Achieving this de- pends on the policies of the authorities at all levels, the development policies of enterprises, and the initiative and creativity of each household. If the local government has clear socio-economic and land-use planning orientations and plans, enterprises have the support and preferential policies for local workers and families that are proactive in converting their livelihoods; the impact of IPs on household economic development in particular and the socio-economic development is generally very positive.

\section{CONCLUSION}

The study aimed to analyze the effect of IP development on the lives of people living around industrial parks in Vietnam. New livelihood strategies are proposed for people living around industrial parks, especially those unemployed due to land acquisition for IPs development in Vietnam. The research results made it possible to achieve the set research objectives, namely: The results of the study have shown that the development of IPs has a positive impact on the lives of people (About $41.36 \%$ of the surveyed people answered that their income increased after having an industrial park). The IP was formed and developed, and this contributed to creating new jobs for people, including direct employment in industrial parks and indirect jobs; these jobs have contributed to changing livelihood strategies for people, opening up new lives for them.

Besides, the development of IPs has also brought benefits such as improved infrastructure, life quality of people changing in a positive direction, thereby giving them opportunities to learn and open up new knowledge, the social communication from different cultures would be the easiest. Research results show that natural resources, social resources, and physical resources have a positive effect on people's lives.

However, in addition to the positive results of the development of IPs, it also causes adverse effects when part of the population does not have a suitable new livelihood strategy and cannot adapt to a new life after losing means of production. These are also shortcomings in the development of industrial parks in Vietnam.

The negative aspects have not been deeply analyzed, and new livelihood strategies formulated for groups of people who are negatively affected by the development of industrial parks are the limitations of this study. This will also be the next research for authors in the future when focusing on exploiting the adverse effects of industrial park development on people's livelihoods, and a new livelihood strategy is proposed specifically for this target group.

\section{AUTHOR CONTRIBUTIONS}

Investigation: Thanh Thuy $\mathrm{Cu}$, Tuan Anh Nguyen.

Methodology: Thanh Thuy Cu.

Resources: Thanh Thuy Cu, Tuan Anh Nguyen.

Software: Tuan Anh Nguyen.

Writing - original draft: Thanh Thuy $\mathrm{Cu}$.

Writing - review \& editing: Thanh Thuy Cu, Tuan Anh Nguyen. 


\section{REFERENCES}

1. Benayas, J. M. R., Ana, M., Jose M. N., \& Jennifer, J. S. (2007). Abandonment of agricultural land: An overview of drivers and consequences. $C A B$ reviews: Perspectives in agriculture, veterinary science, nutrition and natural resources, 2(57), 1-14. https://doi.org/10.1079/PAVSNNR20072057

2. Blomstrom, M., \& Kokko, A. (2002). Multinational Corporations and Spillovers. Journal of Economic Surveys, 12(3), 247-277. https://doi. org/10.1111/1467-6419.00056

3. Bryceson. D. F. (1996). Deagrarianization and rural employment in sub-Saharan Africa: A sectoral perspective. World Development, 24(1), 97-111. https://doi.org/10.1016/0305750X(95)00119-W

4. Bui, T. M. H., Pepijn, S., \& Thomas, B. (2013). Hydropower development in Viet Nam: Involuntary resettlement and factors enabling rehabilitation. Land Use Policy, 31, 536-544. https://doi.org/10.1016/j.landusepol.2012.08.015

5. Bury, J. (2004). Livelihood in transition: Transnational gold mining operation and local change in Cajamarca, Pery. The Geographical Journal, 170, 78-91. https://doi.org/10.1111/j.00167398.2004.05042.x

6. Dai, D., Le, N., \& Nguyen, T.D. (2013). Difficulties in transition among livelihood under agricultural land conversion for industrialization: Perspective of human development. Mediterranean Journal of Social Sciences, 4(10), 259-267. Retrieved from https://www.mcser.org/ journal/index.php/mjss/article/ view/1185

7. DFID. (1999). Sustainable livelihood guidance sheets. Hall- International, Inc. Retrieved from https://www. livelihoodscentre.org/documents/114097690/114438878/Sust ainable+livelihoods+guidance+she ets.pdf/594e5ea6-99a9-2a4e-f288cbb4ae4bea8b?t=1569512091877
8. GSO. (2006). Khao Sat Muc Song Ho Gia Dinh 2006 (Vietnam Household Living Standards Survey 2006). Hanoi, Vietnam: General Statistics Office.

9. Huynh, T. D. X., \& Mai, V. N. (2011). Phan tich cac yeu to anh huong den thu nhap cua ho chan nuoi gia cam o dong bang song cuu long (Analysis of factors affecting the income of poultry farmers in the Mekong Delta). Scientific Journals, 17(b), 87-96. Retrieved from https://sj.ctu.edu.vn/ql/docgia/download/baibao-5447/11.\%20 HUYNH\%20THI\%20DAN\%20 XUAN_87-96_.pdf

10. Hyeong, W. K, Liang, D., Angelo, E. S. C., Minoru, F., Tsuyoshi, F., \& Hung, S. P. (2018). Co-benefit potential of industrial and urban symbiosis using waste heat from industrial park in Ulsan, Korea. Resources Conservation Recycling, 135, 225-234, https:// doi.org/10.1016/j.resconrec.2017.09.027

11. Jansen, H. G. P., John, P., Amy, D., Willem, W., \& Rob, S. (2006). Policies for sustainable development in the hillside areas of Honduras: A quantitative livelihoods approach. Agricultural Economics, 34, 141-153, https:// doi.org/10.1111/j.15740864.2006.00114.x

12. Le, D. P. (2007). Thu nhap, doi song, viec lam cua nguoi dan co dat bi thu hoi de xay dung cac khu cong nghiep, khi do thi ket cau ha tang kinh te- xa hoi cac cong trinh phuc vu loi ich quoc gia (Income, life, work of people whose land is acquired to build industrial parks, urban areas of socio-economic infrastructure, projects serving national interests). National Political Publishing House, Hanoi.

13. Le, L. H., \& Le, T. N. (2020). Determinants of Income Diversification among Rural Households in the Mekong River Delta: The Economic Transition Period. Journal of Asian Finance, Economics and Business, 7(5), 291-304. https://doi.org/10.13106/ jafeb.2020.vol7.no5.291
14. Le, T., Pham, V., Cu, T., Pham, M., \& Dao, Q. (2020). The effect of industrial park development on people's lives. Management Science Letters, 10(7), 1487-1496. https:// doi.org/10.5267/j.msl.2019.12.018

15. Liang, D., Hanwei, L., Liguo Z., Zhaowen L., Zhiqiu, G., \& Mingming, H. (2017). Highlighting regional ecoindustrial development: Life cycle benefits of an urban industrial symbiosis and implications in China. Ecological Modelling, 361, 164-176, https://doi.org/10.1016/j. ecolmodel.2017.07.032

16. Liang, D., Tsuyoshi, F., Ming, D., \& Yong, G. (2015). Towards preventative eco-industrial development: an industrial and urban symbiosis case in one typical industrial city in China. Journal of Clean Production, 114, 387-400. https://doi.org/10.1016/j. jclepro.2015.05.015

17. Milan, D., Rene, W., \& Nikola, M. K. (2013). The effectiveness of industrial zones support in the Czech Republic. Journal of Ekonomika a Management, 16(4), 104-117. Retrieved from http:// www.ekonomie-management.cz/ download/1404732061_cbd8/2013 _4+The+Effectivense+of+Industri al+Zones+Support+in+the+Czech +republic.pdf

18. Nguyen, M. T., Duong, N. T., \& Nguyen, T. N. (2018). Yeu to anh huong den thu nhap cua ho dan sau thu hoi dat xay dung khu cong nghiep tinh Vinh Long (Factors affecting households' income after land acquisition for industrial park construction in Vinh Long province). Scientific Journals, 54(4b), 80-90. https://doi. org/10.22144/ctu.jvn.2018.073

19. Nguyen, T. A. N., \& Nguyen, K. M. (2020). Role of Financial Literacy and Peer Effect in Promotion of Financial Market Participation: Empirical Evidence in Vietnam. Journal of Asian Finance, Economics and Business, 7(6), 73-84. https://doi.org/10.13106/ jafeb.2020.vol7.no6.073 
20. Nguyen, T. D., Nguyen, A. T., Do, P. T. T. (2017). The Role of Investment Attraction in Vietnamese Industrial Parks and Economic Zones in the Process of International Economic Integration. Journal of Asian Finance, Economics and Business, 4(3), 27-34. https://doi. org/10.13106/jafeb.2017.vol4 no3.27

21. Nguyen, V. S. (2009). Industrialisation and urbanisation in Vietnam: How appropriation of agricultural land use rights transformed farmers Livelihoods in a Per-Urban Hanoi Village? (EADN working paper). Retrieved from https://www.landportal.org/library/ resources/mlrf2464/industrialization-and-urbanization-vietnamhow-appropriation-agricultural

22. Nguyen, V. T. (2014). Giao trinh thuc hanh nghien cu trong kinh te va quan tri kinh doanh (Curriculum of research practice in economics and business administration). National Economics University publishing house.

23. Nguyen, Q. N., \& Bui, V. T. (2011). Cac yeu to anh huong den thu nhap cua nguoi dan toc thieu so o vung dong bang song cuu long (Factors affecting the income of ethnic minorities in the Mekong Delta). Scientific Journals, 18(a), 240-245. Retrieved from https:// sj.ctu.edu.vn/ql/docgia/download/baibao-5497/trongtruong_ so18a_27.pdf
24. Nguyen, V. C., McGrath, T., \& Pamela, W. (2006). Agricultural land distribution in Vietnam: Emerging issues and policy implications (MPRA Paper No. 25587). University Library of Munich, Germany. Retrieved from https://mpra.ub.uni-muenchen de/25587/1/MPRA_paper_25587

25. Ramcharran, H. (2017). The impact of workers' remittances on household consumption in India: Testing for consumption Augmentation and stability. Journal of Asian Finance, Economics and Business, 4(4), 51-60. http://dx.doi.org/10.13106/ jafeb.2017.vol4.no4.51

26. Ramona, F. P. (2008). Ecoindustrial parks - an opportunity for the developing countries to achieve sustainable development. Zagreb International Review of Economics and Business, 11(special issue), 21-33. Retrieved from https://hrcak.srce.hr/78666

27. Rohan, N., Philip, K., Elliston, L., \& King, J.A. (2005). Structural adjustment: a vulnerability index for Australian broadacre Agriculture. Australian Commodities, 12(1), 171-179. Retrieved from https://www. econbiz.de/Record/structuraladjustment-a-vulnerability-indexfor-australian-broadacre-agriculture-nelson-rohan/10003282098

28. Saumik, P., \& Sarma, V. (2013). The livelihood effects of industrialization on displaced households: Evidence from Falta special economic zone, West Bengal. Centre for European Economic Research Discussion, 13(83), 1-32. http://dx.doi. org/10.2139/ssrn. 2343143

29. Siegel. (2005). Using an assetbased approach to identify drivers of sustainable rural growth and poverty reduction in Central America: A conceptual framework (World Bank Policy Research Working Paper 3475). Retrieved from https://openknowledge. worldbank.org/handle/10986/8945

30. Susur, E., Hidalgo, A., \& Chiaroni, D. (2019). A strategic niche management perspective on transitions to eco-industrial park development: A systematic review of case studies. Resources Conservation Recycling, 140, 338359, https://doi.org/10.1016/j. resconrec.2018.06.002

31. Tran, Q.T. (2013). Livelihood strategies for coping land loss among households in Vietnam's sub-urban areas. Asian Social Science, 9(15), 33-46. https://doi. org/10.5539/ass.v9n15p33

32. Tran, Q. T., \& Vu, V. H. (2014). The impact of land loss on household income: The case of HaNoi's sub-urban areas, Viet Nam. International Journal of Business and Society, 15(2), 339358. Retrieved from http://www. ijbs.unimas.my/repository/pdf/ Vol15-no2-paper9.pdf 